\title{
PERANAN SENAM OTAK DALAM MENINGKATKAN FUNGSI MEMORI JANGKA PENDEK PADA ANAK
}

\section{THE ROLE OF BRAIN GYM IN IMPROVING THE SHORT-TERM MEMORY FUNCTION TO CHILDREN}

\author{
Eka Damayanti1), Jamilah'), Alwan Suban ${ }^{3)}$, Fitriana'), Nur Alamsyah"5) \\ 1,2,3,4,5)Universitas Islam Negeri Alauddin Makassar \\ eka.damayanti@uin-alauddin.ac.id ${ }^{11}$, jamilah@uin-alauddin.ac.id²), alwan.suban@uin- \\ alauddin.ac.id ${ }^{3}$ ), fitriana2800@gmail.com ${ }^{4}$, nralamsyah03@gmail.com ${ }^{5)}$
}

\begin{abstract}
Abstrak
Tujuan studi ini untuk mengetahui secara teoritik peranan senam otak dalam meningkatkan fungsi memori jangka pendek (short term memory) pada anak. Penelitian kualitatif jenis studi kepustakaan ini dilakukan dengan mengumpulkan berbagai sumber dari jurnal dan buku terkait dengan fokus kajian. Analisis data yang digunakan berupa analisis naratif deskriptif. Hasil penelusuran menunjukkan gerakan yang dilakukan dalam senam otak dapat meningkatkan fungsi memori jangka pendek yang terbukti dengan kemajuan kemampuan anak dalam membaca. Gerakan senam otak melatih daerah sensorik otak sehingga daya tahan informasi yang didapat bertahan lebih lama membuat memori lebih kuat sehingga membuat proses belajar lebih mudah dan menghilangkan hambatan belajar. Senam otak sangat dianjurkan untuk anak-anak yang kemampuan matematikanya belum optimal. Hasil penelitian ini mengimplikasikan pada guru, orang tua atau pengasuh anak untuk senantiasa memberikan stimulus berupa senam otak pada anak agar dapat meningkatkan fungsi otak dan membuat tubuh rileks sehingga semangat dalam belajar sehingga dapat meningkatkan prestasi belajar.
\end{abstract}

Kata Kunci: anak, memori jangka pendek, senam otak

\begin{abstract}
The purpose of this study is to know how the brain gym improves short term memory function to children. This qualitative research with a literature study was conducted by collecting various sources from journals and books related to the focus of the study. The data analysis used was descriptive narrative analysis. The results showed that the movements in the brain gym can improve short-term memory function that is the progress of children's ability to read. Brain gym movements train the sensory areas of the brain so that the resistance of the information lasts longer, makes memory stronger, making the learning process easier and eliminating learning obstacles. Based on the study, a brain gym is highly recommended for children whose mathematical abilities are not yet optimal. It implies that teachers, parents, or caregivers should provide a stimulus in the form of brain gym to children. With that stimulus, it can improve brain function and relax the body. The children become more enthusiastic and improve their learning achievement.
\end{abstract}

Keywords: children, short term memory, brain gym

How to Cite: Damayanti, E., Jamilah, Suban, A., Fitriana, \& Alamsyah, N. (2020). Peranan senam otak dalam meningkatkan fungsi memori jangka pendek pada anak. Al asma: Journal of Islamic Education, 2(2), 247-254. 


\section{PENDAHULUAN}

Memori jangka pendek berperan besar dalam aspek perkembangan kognitif sehingga memberikan pengaruh terhadap intelegensia dan prestasi akademik anak. Setiap kejadian yang dialami oleh seseorang dalam beberapa menit pasca kejadian akan tersimpan dalam memori jangka pendek. Memori jangka pendek (memori kerja) berperan pemecahan masalah yang posisinya berada dalam pikiran sadar. Kecepatan proses kognitif diketahui bergantung dari derajat aktivasi memori jangka pendek (Wulandari dkk, 2018). Menurut Marpaung dan Alfonsus (2017) memori jangka pendek mempunyai peranan dalam pikiran sadar. Memori jangka pendek lebih sering digunakan untuk mencoba memecahkan masalah dan menggunakannya untuk menyimpan bagian-bagian masalah serta informasi yang diambil dari memori jangka panjang yang relevan dengan masalah.

Memori jangka pendek berfungsi menyimpan material yang dibutuhkan dalam periode waktu yang pendek dan juga sebagai ruang kerja untuk perhitungan mental, kemungkinan fungsi yang lain yaitu memori jangka pendek yang merupakan stasiun perhentian untuk selanjutnya informasi dibawa ke memori jangka panjang. Artinya, informasi mungkin berada di memori dalam waktu yang relatif singkat dan sementara ia sedang disandikan menjadi memori jangka panjang (Putranto, 2009). Oleh karena itu peran memori jangka pendek sangat besar untuk kehidupan manusia.

Desiningrum dan Febriana (2010) menjelaskan bahwa seseorang dengan tingkat kecerdasan yang rendah dapat membuat kapasitas belajar anak menjadi terbatas sehingga untuk hal-hal yang sifatnya abstrak, anak-anak jadi sulit untuk fokus atau berkonsentrasi pada pelajaran yang diterima, kurang mampu dalam mengikuti petunjuk yang diberikan, kurang kreatif dan inisiatif, serta memiliki keterbatasan dalam mengingat pelajaran (memori jangka pendek yang kurang baik). Wade \& Tavris (2007) mengungkapkan amnesia dapat terjadi apabila memori jangka pendek pada anak kurang baik, sehingga anak tidak mampu bersikap kreatif dan dapat membuat fungsi otak bertambah menurun serta tidak dapat berfungsi dengan baik.

Daya ingat dan konsentrasi seseorang dapat ditingkatkan dengan melakukan serangkaian gerakan yaitu dengan melakukan senam otak. Adapun manfaat senam otak yaitu, dapat mengasah sensitivitas telinga untuk mendengar sehingga kemampuan pendengaran makin tajam, merangsang bagian otak yang menerima informasi (receptive) dan bagian yang menggunakan informasi (expressive) sehingga memudahkan proses mempelajari hal-hal baru, dan dapat mengembalikan vitalitas otak setelah serangkaian aktivitas yang melelahkan, mengusir stress, meningkatkan konsentrasi dan perhatian serta meningkatkan kemampuan memahami dan berpikir rasional. Selain itu, menurut Donczik (2001) senam otak dapat meningkatkan kefasihan dalam membaca, kecepatan pemahaman serta fungsi memori jangka pendek dan jangka panjang pada anak-anak disleksia.

Pratiwi, Handoko, dan Rahmatania (2016) mengatakan bahwa senam otak merupakan serangkaian latihan gerak sederhana untuk meningkatkan kemampuan belajar peserta didik dengan menggunakan otak secara keseluruhan. Gerakan-gerakan dalam senam otak memiliki banyak manfaat. Senam otak membuat siswa lebih mudah dalam menerima segala macam pelajaran dan dapat memahaminya dengan baik, serta memiliki banyak manfaat bagi kemampuan akademik siswa (Dennison, 2003). Menurut Martini dkk. (2016) untuk memudahkan peserta didik dalam kegiatan belajar maka senam otak sangat 
bagus untuk diberikan. Selain itu, senam otak juga mempermudah dalam melakukan penyesuaian terhadap ketegangan, tantang dan tuntutan kehidupan sehari-hari serta dapat meningkatkan kemampuan berbahasa dan daya ingat.

Senam otak (brain gym) pertama kali diciptakan oleh Paul E. Dennison, Ph.D pada tahun 1980. Senam otak memiliki banyak manfaat dalam meningkatkan berbagai aspek perkembangan yaitu dapat meningkatkan kemampuan berbahasa dan daya ingat, orang menjadi lebih antusias dan bersemangat, kreatif dan efisien, orang merasa lebih sehat akibat berkurangnya stress, prestasi belajar dan bekerja menjadi lebih meningkat. Otak manusia, seperti halogram, yang terdiri dari tiga dimensi dengan bagian-bagian yang memiliki hubungan dan membentuk satu kesatuan. Akan tetapi, otak manusia memiliki tugas yang spesifik di mana ketiga dimensi tersebut dalam aplikasi gerakan senam otak disebut dengan istilah dimensi lateralitas, dimensi pemfokusan serta dimensi pemusatan. Senam otak dapat mengaktifkan otak sehingga mampu bekerja lebih optimal. Senam otak telah diakui sebagai salah satu teknik belajar yang paling baik oleh National Learning Foundation USA karena senam otak ini dapat memberikan keuntungan yaitu dapat membuat seseorang belajar dan bekerja dalam keadaan tidak stress, dapat dilakukan hanya dalam kurun waktu yang sangat singkat yaitu kurang dari 5 menit, tidak memerlukan bahan atau tempat yang khusus, dapat dipakai dalam semua dan kondisi atau situasi belajar/ bekerja juga dalam aktivitas sehari-hari, meningkatkan kepercayaan diri, menunjukkan hasil dengan segera, efektif dalam menangani seorang yang mengalami hambatan dan stres belajar, membuat seseorang mandiri dalam belajar dan mengaktifkan seluruh potensi dan keterampilan yang dimiliki oleh seseorang (Dennison, 2003). Artikel ini mencoba menguraikan pesan senam otak dalam peningkatan fungsi memori jangka pendek.

\section{METODE PENELITIAN}

Jenis penelitian yang digunakan berupa penelitian kualitatif jenis studi kepustakaan (library research) yaitu dengan mengumpulkan data dari buku, artikel, web, ataupun informasi lain yang berhubungan dengan masalah tersebut. Pada penelitian ini fokus pencarian pada senam otak dan memori jangka pendek (short term memory). Proses analisis data pada penelitian ini menggunakan analisis narasi deskriptif melalui jalan reduksi data, penyajian data, dan konklusi data.

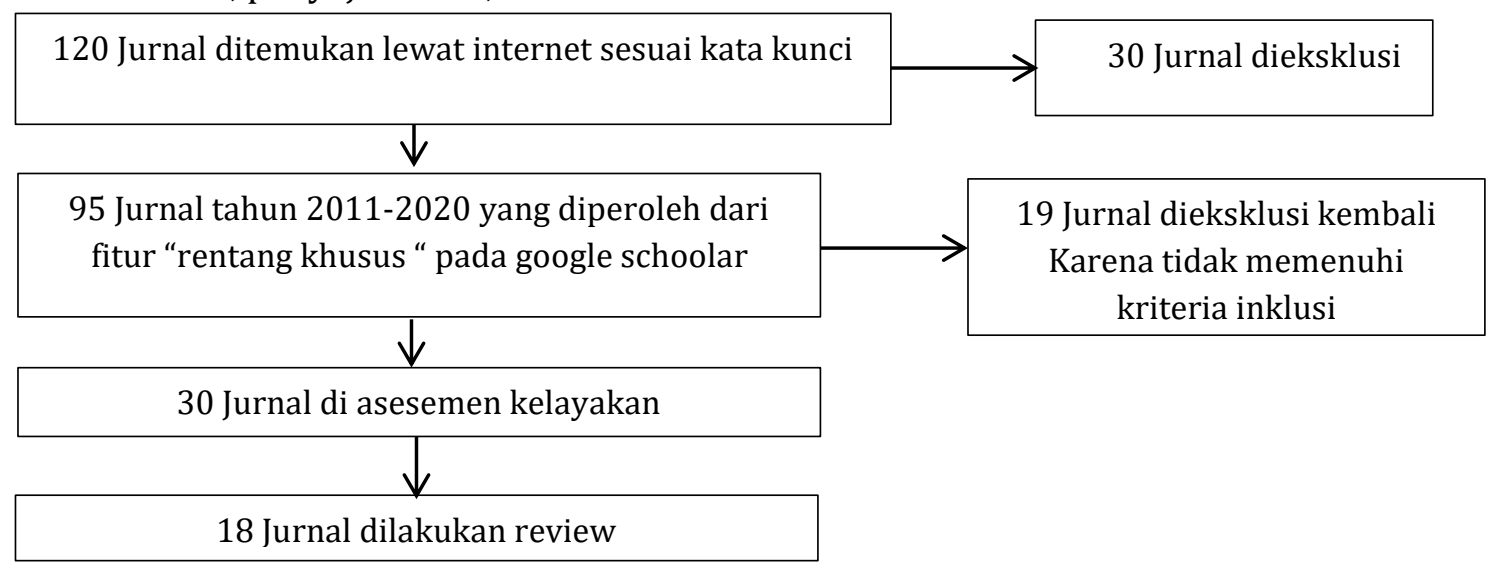

Gambar 1. Sistematika Pencarian Referensi 


\section{HASIL DAN PEMBAHASAN}

Hasil penelusuran peneliti terhadap artikel terkait senam otak dan memori jangka pendek ditemukan peran senam otak sangat besar dalam peningkatan fungsi memori jangka pendek. Secara umum terdapat tiga temuan utama, yakni (1) senam otak memaksimalkan kerja otak; (2) senam otak meningkatkan daya ingat; dan (3) senam otak mengurangi stres dan mendorong relaksasi; (4) senam otak dapat meningkatkan keseimbangan tubuh.

\section{Senam Otak Memaksimalkan Fungsi Kerja Otak}

Senam otak cenderung memiliki ritme yang lambat dalam prosesnya dan memberikan stimulus yang baik dengan tujuan untuk mengoptimalkan fungsi kerja otak (Pratiwi et al, 2016). Struktur otak berubah secara dramatis dengan stimulus yang diberikan (Rohman, 2015). Senam otak (brain gym) merupakan rangkaian latihan berbasis gerakan tubuh sederhana. Gerakan tersebut dapat berupa gerakan silang, delapan tidur, putaran leher, burung hantu, pasang kuda-kuda, pasang telinga, titik positif, dan sakelar otak (Putranto, 2009).

Senam yang termasuk kegiatan berolahraga mengakibatkan terjadinya vasodilatasi pembuluh darah dan meningkatkan denyut jantung sehingga sirkulasi darah dapat tersebar seluruh tubuh, termasuk otak. Peningkatan sirkulasi darah dapat memperlancar penyuplaian nutrisi dan oksigen sehingga memaksimalkan fungsi kerja otak, termasuk kemampuan daya ingat atau memori jangka pendek (Susanto et al., 2009).

Senam otak (brain gym) adalah rangkaian latihan yang membuat tubuh bergerak secara sederhana. Senam otak merupakan stimulus yang baik dalam mengoptimalkan fungsi kerja otak, dimana gerakan pada senam otak cenderung memiliki ritme yang lambat dan memiliki tujuan tertentu. Senam otak telah diakui sebagai salah satu teknik belajar yang paling baik oleh National Learning Foundation USA (Dennison, 2003).

\section{Senam Otak Meningkatkan Daya Ingat}

Gerakan-gerakan dalam senam otak memiliki manfaat dalam banyak hal terutama dalam membuat otak menjadi rileks, meningkatkan ingatan, menghilangkan beban pikiran, menjaga keseimbangan, meningkatkan konsentrasi, meningkatkan energi, melancarkan dan menstabilkan asupan yang dapat memacu kesehatan jasmani dan rohani. Latihan senam otak menstimulasi hipokampus yang mempengaruhi kemampuan memori jangka pendek (Akbarjono \& Saputra, 2019).

Putranto (2009) dalam penelitiannya menggunakan senam otak untuk meningkatkan kemampuan memori jangka pendek. Selain itu, Suryatika \& Wijarnako (2019) mengatakan bahwa senam otak merupakan gerakan yang dilakukan agar harmonisasi dapat terjaga dan mengoptimalkan kinerja otak bagian kiri dan kanan. Berdasarkan penelitian Gea (2016) menemukan bahwa senam otak dapat meningkatkan kemampuan konsentrasi siswa dalam belajar yang dibuktikan dengan adanya perbedaan signifikan tingkat konsentrasi belajar antara kelompok eksperimen setelah diberi perlakuan yang berupa brain gym dengan kelompok kontrol.

Peningkatan memori jangka pendek melalui senam otak dapat disebabkan karena terjadi peningkatan atensi setelah melakukan senam otak (Astuti, 2015). Senam otak akan mengaktifkan mekanisme integrasi pada otak. Gerakan-gerakan pada senam otak merupakan jembatan yang membentuk koneksi atau hubungan antara otak dan tubuh. Gerakan pada senam otak dapat mengaktifkan organ dan sistem pada tubuh manusia 
melalui kerja sistem saraf dengan membagi gerakan-gerakan pada tiga dimensi, yaitu dimensi lateralis, dimensi pemfokusan dan dimensi pemusatan. Dimensi-dimensi tersebut berkaitan dengan fungsi otak yang spesifik dan menggambarkan penggunaan otak secara menyeluruh dalam proses belajar. Pola tiga dimensi dalam senam otak bertujuan untuk menciptakan kongruensi dimana akses putaran cepat dan putaran lambat bisa terintegrasi pada tiga dimensi ini. Karena keadaan seimbang hanya bisa tercipta bila semua tiga dimensi bekerja secara konsisten (Robot, 2019).

Rayung Cahyaning Astuti (2015) dalam penelitiannya menemukan bahwa senam otak dapat meningkatkan kemampuan membaca dengan meningkatkan kemampuan memori, dimana fungsi memori jangka pendek berperan penting dalam kemampuan membaca. Gerakan senam otak melatih daerah sensorik otak sehingga daya tahan informasi yang didapat bertahan lebih lama dan membuat memori lebih kuat serta meningkatkan kemampuan membaca. Latihan senam otak merupakan solusi sederhana dalam mengatasi kesulitan-kesulitan pada anak maupun orang dewasa seperti kesulitan membaca, menulis, menghitung, berbahasa, olahraga, dan musik (Putri dkk., 2012).

\section{Senam Otak Mengurangi Stres dan Mendorong Relaksasi}

Bagi orang yang merasa sulit untuk belajar, terkadang memaksakan diri untuk belajar sehingga seseorang dapat mengalami stress akibat tekanan yang dapat mengakibatkan melemahnya fungsi pada bagian-bagian tertentu pada otak (Yenny, 2019). Stress yang berkepanjangan juga dapat mengakibatkan kerusakan memori (Rossman, 2010). Hal tersebut dapat diatasi dengan brain gym. Penelitian yang dilakukan oleh Sari (2010) menunjukkan bahwa senam otak mengurangi jumlah stress pada siswa yang mengalami stress sedang dan stress tinggi.

Senam otak merupakan serangkaian gerakan sederhana yang menyenangkan yang berfungsi untuk meningkatkan kemampuan belajar (Desiningrum, 2016). Brain gym membuat bagian-bagian otak yang sebelumnya tertutup atau terhambat menjadi terbuka sehingga kegiatan belajar atau bekerja dapat menggunakan seluruh otak atau whole brain learning (Yenny, 2019) dan dapat merilekskan anggota tubuh sehingga siap menerima informasi dan pelajaran (Rossman, 2010).

Daya ingat siswa dapat menjadi baik kembali dengan memberikan perlakuan berupa senam otak (Prasetyo \& Saputra, 2017). Senam otak juga mampu mengembalikan kelenturan dan posisi saraf dan aliran darah yang akan berpengaruh meningkatkan relaksasi. Senam otak merangsang proses penurunan aktifitas saraf simpatis dan peningkatan saraf parasimpatis yang akan berpengaruh pada penurunan hormon adrenalin, norepinefrin dan katekolamin serta vasodilatasi pada pembuluh darah yang menyebabkan transport oksigen ke seluruh tubuh terutama otak lancar, sehingga terjadi peningkatan relaksasi (Henny, 2018).

Menurut Handayani, Rusminingsih, dan Sari (2012) melalui pelatihan senam otak, siswa dapat menjadi lebih siap dalam proses penerimaan materi pelajaran yang baru, memperbaiki daya ingat dan konsentrasi, menjadikan siswa lebih mampu untuk berkomunikasi, membaca, dan meningkatkan prestasi belajar serta mengendalikan emosi. Sehingga diharapakan agar orang tua siswa dapat mengenal pengetahuan tentang senam otak, agar orang tua dapat memiliki peran yang besar dalam mengoptimalkan proses belajar anak. 


\section{Senam Otak Dapat Meningkatkan Keseimbangan Tubuh}

Menurut Nafarin dan Widodo (2016) latihan senam otak merupakan salah satu upaya yang dapat dilakukan dalam meningkatkan keseimbangan tubuh pada anak. Senam otak atau brain gym adalah serangkaian latihan berbasis gerakan tubuh sederhana. Gerakan itu dibuat untuk merangsang otak kiri dan kanan (dimensi lateralis), meringankan atau merelaksasi belakang otak dan bagian depan otak (dimensi pemfokusan), merangsang sistem yang terkait dengan perasaan/emosional, yakni otak tengah (limbik), serta otak besar (dimensi pemusatan) dan bermanfaat meningkatkan kemampuan berbahasa, konsentrasi, daya ingat meningkat, menjadi lebih bersemangat, lebih kreatif dan efisien, serta merasa lebih sehat.

Wardani (2014) mengatakan bahwa senam otak merupakan gerakan yang dapat dilakukan dimana saja dan kapan saja dimana setiap bagian-bagian pada otak dapat diseimbangkan dengan melakukan gerakan sederhana atau latihan berbasis gerakan tubuh sederhana. Pemberian rangsangan atau stimulus pada otak dengan melakukan gerakan ringan pada permainan olah tangan dan kaki dapat meningatkan keseimbangan serta harmonisasi antara logika dengan kontrol emosi, panca indra dapat berkerja secara optimal dan keseimbangan serta kelenturan tubuh dapat terjaga.

Menurut Purnamasari dkk. (2018) salah satu upaya yang dapat dilakukan ketika terdapat gangguan pada motorik halus adalah senam otak/brain gym karena senam otak dapat merangsang perkembangan seluruh bagian otak, baik otak kanan, otak kiri, otak depan, maupun otak belakang secara sinergis. Putranto (2009) dalam penelitiannya juga menggunakan gerakan senam otak yang khusus serta efektif dalam meningkatkan fungsi kerja dari memori jangka pendek

\section{SIMPULAN}

Senam otak sangat berperan dalam peningkatan fungsi memori jangka pendek, yakni (1) senam otak memaksimalkan kerja otak; (2) senam otak meningkatkan daya ingat; dan (3) senam otak mengurangi stres dan mendorong relaksasi; (4) senam otak dapat meningkatkan keseimbangan tubuh. Oleh karena itu direkomendasikan kepada pendidik atau orangtua untuk senantiasa memberikan latihan senam otak pada anak dalam bentuk dan model yang disesuaikan dengan tingkat usia anak.

\section{DAFTAR PUSTAKA}

Akbarjono, A. I. W., \& Saputra, A. (2019). Senam otak (brain gym) meningkatkan memori jangka pendek (short memory) pada anak tuna grahita ringan usia 8-9 tahun. Institut Agama Islam Negeri Bengkulu.

Astuti, R. C. (2015). Pengaruh senam otak terhadap memori jangka pendek siswa sekolah dasar di SD Negeri 34 Pontianak kota tahun 2014. Universitas Tanjung Pura.

Dennison, P. E. (2003). Brain gym (senam otak). PT Grasindo.

Desiningrum, D. R. (2016). Terapi senam otak untuk menstimulasi kemampuan memori jangka pendek pada anak autis. Jurnal Psikologi, 43(1), 30-41.

Desiningrum, D. R., \& Febriana, I. (2010). Menstimulasi kemampuan kognitif (atensi, fokus pemahaman, konsentrasi, dan memori jangka pendek) anak autis melalui terapi senam otak. Universitas Diponegoro. 
Donczik, J. (2001). Konnen edukinestetishe ubungen (brain gym). Brain Gym Hournal, XV, 297-305.

Drabben-Thiemann, G., Hedwig, D., Kenklies, M., Blogberg, V., Marahrens, A., Marahrens, G., \& Hager, K. (2002). The effect of brain gym on the cognitive performance of alzheimer's patients. Brain Gym Journal, 16(1).

Gea, S. R. (2016). Pengaruh brain gym (senam otak) terhadap memori jangka pendek penyandang tunagrahita ringan di SDLB-C Dharma Asih Pontianak. Jurnal ProNers, $3(1)$.

Handayani, S., Rusminingsih, E., \& Sari, D. K. (2012). Pengaruh senam otak terhadap memori jangka pendek anak retardasi ental di SLB Shanty Yoga Klaten.

Henny, A. S. (2018). Pengaruh senam otak terhadap fungsi kognitif dan kualitas tidur pada lansia di puskesmas rantang medan. Jurnal Mutiara, 1(1), 44-56.

Marpaung, D. R., \& Alfonsus, Y. (2017). Pengaruh pemberian senam otak terhadap memori jangka pendek pada mahasiswa ikor FIK Unimed. Sains Olahraga: Jurnal Ilmiah Ilmu Keolahragaan, 1(1), 21-29.

Martini, A., Fitriangga, A., \& Fahdi, F. K. (2016). Pengaruh senam otak terhadap perubahan daya ingat (fungsi kognitif) pada lansia di panti sosial tresna werdha mulia dharma kubu raya. Jurnal ProNers, 3(1), 1-15.

Moffat, K., Mcconnachie, A., Ross, S., \& Morrison, J. M. (2004). First year medical student stress and coping in a problem-based learning medical curriculum. Medical Education, 38(5), 482-491.

Nafarin, M. F., \& Widodo, A. (2016). Pengaruh senam otak terhadap keseimbangan dinamis pada anak usia 7-8 tahun di SD Negeri Pabelan 03 Mendungan Kartasura Sukoharjo. Fisioterapi Universitas Muhammadiyah Surakarta.

Prasetyo, W., \& Saputra, S. A. (2017). Pengaruh senam otak terhadap daya ingat anak kelas V Sekolah Dasar. Jurnal Keperawatan STIKES.

Pratiwi, S. E., Handoko, W., \& Rahmatania, R. (2016). Pengaruh senam otak terhadap memori jangka pendek mahasiswa. Jurnal Vokasi Kesehatan, 1(16), 1-9.

Purnamasari, L., Wahyuni, T. D., \& Putri, R. M. (2018). Pengaruh senam otak terhadap peningkatan motorik halus pada anak usia 3-4 tahun di paud mawar tlogomas Malang. Nursing News: Jurnal Ilmiah Keperawatan, 3(1).

Putranto, P. L. (2009). Pengaruh senam otak terhadap fungsi memori jangka pendek anak dari keluarga status ekonomi rendah. universitas Dipenogoro, Semarang.

Putri, D. M. P., Nurrachmah, E., \& Gayatri, D. (2012). Pengaruh latihan senam otak dan art therapy terhadap fungsi kognitif lansia dengan dimensia di pstw yogyakarta unit budi luhur dan abiyoso. Universitas Indonesia.

Robot, J. I. (2019). Penambahan senam otak pada program Senam Sehat Anak Indonesia (SSAI) dapat meningkatkan memori jangka pendek dan indeks kesegaran jasmani siswa SD Inpres Padang. Sport and Fitness Journal, 7(1), 10-19.

Rohman, S. Nu. (2015). Pengaruh latihan senam otak (brain gym) terhadap peningkatan kemampuan memori jangka pendek pada anak tuna grahita ringan di SDLB ABC Swadaya Kenda. 
Rossman, M. (2010). Stress influence to short-range memory and longterm.

Sari, O. F. (2010). Pengaruh senam otak terhadap tingkat stress pada anak usia sekolah kelas 4 dan 5 di SD Negeri Wajo Bangunharjo Sewon Bantul. Sekolah Tinggi Ilmu Kesehatan Aisyiah, Yogyakarta.

Suryatika, A. R., \& Wijarnako, H. P. (2019). Penerapan senam otak terhadap fungsi kognitif pada lansia dengan demensia. Jurnal Manajemen Asuhan Keperawatan, 3(1), 2836.

Susanto, Y., Pinandjojo, Djojosoewarno, \& Rosnaeni. (2009). Pengaruh olahraga ringan terhadap memori jangka pendek pada wanita dewasa. Juornal of Medicine and Health, 8(2), 144-150.

Sutrisno, R. T., Supatmo, Y., \& Nugraheni, A. (2019). Pengaruh olahraga jalan cepat terhadap memori jangka pendek pada kelompok dewasa muda. Diponegoro Medical Journal (Jurnal Kedokteran Diponegoro), 8(1), 428-435.

Wade, C., \& Tavris, C. (2007). Psikologi. Erlangga.

Wardani, N. N. S. (2014). Pengaruh terapi senam otak (brain gym) terhadap daya ingat jangka pendek pada lansia di banjar muncan kapal mengwi badung. Jurnal Dunia Kesehatan, 5(1), 38-41.

Wulandari, A. P., Saroinsong, H. E., \& Wulandari, A. (2018). Pengaruh senam otak (brain gym) terhadap memori jangka pendek mahasiswa tingkat akhir Fakultas Kedokteran Universitas Jenderal Achmad Yani. Fk Unjani Press.

Yenny. (2019). Analaisis praktik klinik keperawatan pada klien stroke non hemoragik dengan intervensi inovasi terapi musik klasik dan senam otak terhadap peningkatan memori jangka pendek di ruang stroke center RSUD Abdul Wahab Syahrani Samarinda Tahun 2018. Universitas Muhammadiyah Kalimantan Timur. 